Sains Malaysiana 50(12)(2021): 3583-3592

http://doi.org/10.17576/jsm-2021-5012-10

\title{
Analysis of Biogas Production from Biomass Residue of Palm Oil Mills using an Anaerobic Batch Test
}

(Analisis Penghasilan Biogas daripada Sisa Biojisim Kilang Minyak Sawit menggunakan Ujian Kelompok Anaerob)

\author{
Norashikin Ahmad KamaL*, Siti Nooraihanah Osman, LeE Dong YeOl \& MARfiah AB Wahid
}

\section{ABSTRACT}

The Malaysian palm oil industry has grown rapidly due to Malaysia's tropical weather and suitable terrain. Palm oil production is now categorized as the most significant agriculture-based industry in the country. Along with strong economic returns, the palm oil industry also generates an abundance of waste products, including empty fruit bunches (EFB) (23\%), mesocarp fibre (12\%), shells (5\%) and palm oil mill effluent (POME) (60\%) for every batch of fresh fruit bunches (FFB) processed in the mills. This study is meant to fill the gap from previous studies in terms of biogas productions from the POME or the combination of POME and EFB which normally been conducted under the thermophilic conditions. The appropriate mixture ratios between POME and EFB in anaerobic digestion will reduce time of treatment and space if been conducted in the low temperature (mesophilic conditions). Thus, this paper is focuses on the analysis of batch test design which consist of low temperature (mesophilic, 20-40 ${ }^{\circ} \mathrm{C}$ ) conditions for evaluating the performance of biogas production from the combination of POME and EFB in anaerobic digestion. The aim was to determine the amount of biogas production based on different ratios of POME and EFB mixtures. Biogas 1, containing $160 \mathrm{~mL}$ of fresh POME mixed with $40 \mathrm{~g}$ of EFB, was shredded and blended with $1800 \mathrm{~mL}$ seed sludge. Biogas 2, containing $120 \mathrm{~mL}$ of fresh POME mixed with $80 \mathrm{~g}$ of EFB, was shredded and blended with $1800 \mathrm{~mL}$ seed sludge. Based on the analysis of the results, the total production of Biogas 1 was greater than that of Biogas 2. The findings also show that the ratio of POME and 20\% EFB (Biogas 1) was more efficient in producing the biogas compared to the ratio POME and 40\% EFB (Biogas 2) under the mesophilic conditions. Thus, the mesophilic conditions required energy saving and low-cost process, compared to the previous studies which used the high temperature (thermophilic, $41-122^{\circ} \mathrm{C}$ ) that definitely was costly and require more energy consumption. This study will serve as preliminary results for enhancing the treatment methods use in Malaysia and form the early basis for the development of a new technology incorporating a combination of POME and EFB.

Keywords: Biogas production; empty fruit bunch (EFB); palm oil mill effluent (POME)

ABSTRAK

Industri minyak kelapa sawit Malaysia telah membangun secara pesat disebabkan oleh cuaca tropika di Malaysia dan rupa bumi yang sesuai. Pada masa ini, penghasilan minyak kelapa sawit telah dikategorikan sebagai industri pertanian yang terpenting di dalam negara ini. Selain daripada pulangan ekonomi yang besar, industri minyak kelapa sawit kaya dengan penghasilan hasil buangan, termasuk tandan buah kosong (EFB) (23\%), fiber mesokarp (12\%), cangkerang (5\%) dan efluen minyak kelapa sawit (POME) (60\%) untuk setiap kelompok tandan buah segar yang diproses di kilang. Kajian ini bertujuan untuk melengkapkan kajian lepas dari segi produksi biogas daripada penghasilan POME atau gabungan POME dan EFB yang kebiasaannya dijalankan di bawah keadaan termofili. Nisbah campuran yang sesuai antara POME dan EFB dalam proses pencernaan anaerob akan menurunkan masa rawatan dan ruang sekiranya ujian ini dijalankan pada suhu yang rendah (keadaan mesofili). Oleh itu, kajian ini adalah berfokuskan pada analisis ujian reka bentuk kelompok yang terdiri daripada keadaan suhu rendah (mesofili, 20-40 ${ }^{\circ} \mathrm{C}$ ) untuk menilai prestasi penghasilan biogas daripada penggabungan POME dan EFB dalam proses pencernaan anaerob. Tujuan kajian ini adalah untuk menentukan jumlah penghasilan biogas berdasarkan daripada penggunaan nisbah campuran POME dan EFB yang berbeza. Biogas 1 mempunyai 160 mL POME segar yang dicampurkan dengan $40 \mathrm{~g}$ EFB, campuran ini dicincang dan dikisar dengan 1800 mL benih enap cemar. Biogas 2 mempunyai 120 mL POME segar yang dicampurkan dengan $80 \mathrm{~g}$ EFB, campuran ini dicincang dan dikisar dengan 1800 mL benih enap cemar. Berdasarkan keputusan analisis, jumlah penghasilan Biogas 1 adalah lebih tinggi daripada Biogas 2. Penemuan kajian juga menunjukkan bahawa nisbah POME dan 20\% EFB (Biogas 1) adalah lebih cekap dalam penghasilan biogas sekiranya dibandingkan dengan nisbah POME dan $40 \%$ 
EFB (Biogas 2) di bawah keadaan mesofili. Oleh itu, keadaan mesofili adalah diperlukan atas sebab jimat tenaga dan proses yang murah jika dibandingkan dengan kajian lepas yang menggunakan suhu tinggi (termofili, 41-122 ${ }^{\circ} \mathrm{C}$ ) yang memerlukan penggunaan tenaga yang tinggi dan proses yang lebih mahal.

Kata kunci: Efluen minyak kelapa sawit (POME); penghasilan biogas; tandan buah kosong (EFB)

\section{INTRODUCTION}

The Malaysian palm oil industry has grown rapidly over the past few years due to its suitable weather and land. The industry is now the most significant agriculturally-based industry in the country. According to Ludin et al. (2014) areas planted with palm oil in Malaysia constitute $14 \%$ of its total land area, at 33 million ha. Expansion has occurred mainly in Sabah and Sarawak, with a combined growth of $4.5 \%$, as compared to $1.6 \%$ in Peninsular Malaysia. Sabah remains the largest oil palm producer, with 1.24 million hectares or $30 \%$ of total planted area (Sulaiman et al. 2011).

In 2010, palm oil accounted for $36.5 \%$ of the world's vegetable oil production. By 2016, palm oil produced by Malaysia was projected to be the leading vegetable oil in the world due to rising demand (Choong \& McKay 2014).

Along with strong economic returns, the palm oil industry also generates an abundance of waste, including EFB (23\%), mesocarp fibre (12\%), shells (5\%) and POME $(60 \%)$ for every tonne of FFB processed in the mills (Baharuddin et al. 2010).

The quantity of waste generated depends on the quality of the initial raw material (Prasertsan \& Prasertsan 1996). A previous study by Hasanudin et al. (2015) described mass balance analysis carried out at Bekri Palm Oil Mill Lampung, Indonesia. They discovered that oil extraction rate (OER) of crude palm oil (CPO) processing was about $21.8 \%$ of each FFB. The growth of the palm oil industry has greatly boosted Malaysia's economy due to the abundance of by-products such as POME, EFB, palm kernel shell (PKS) and mesocarp fibre (Bala et al. 2014). Based on a previous study by Prasertsan and Prasertsan (1996), more than 70\% (by weight) of the processed FFB is left over as palm oil waste. By products such as shell, decanter cake and EFB make up $30 \%, 6 \%, 3 \% \& 28.5 \%$ of waste, respectively (Pleanjai et al. 2004). Yacob et al. (2006) stated that Malaysia's palm oil mills produce approximately 30 million tonnes of POME and about 26.7 million tonnes of solid biomass.

As reported by Ahmad et al. (2003), POME (raw or partially treated) has a very high content of degradable organic matter caused by presence of unrecovered palm oil. Such extremely contaminated wastewater will pollute waterways because of the depletion of oxygen and other related effects. Land dumping is the most acceptable dumping method, because incineration is prohibited for EFB due to potential environmental and health problems caused by haze (Schuchardt et al. 2008). The discovery of potential uses for the biomass by-products of palm oil mills would be beneficial as an energy recovery source, as waste generation continues to increase annually. Purnomo et al. (2018) successfully derived biogas from the EFB of post-mushroom-cultivation media. Waste to energy is an excellent solution for managing waste due to the depletion of raw energy sources and the prevention of environmental degradation. Thus, the integration of renewable energy technology and waste management must be explored. To relate with the previous statements, the current study will serve as preliminary research to improve waste management technologies. The objectives of this study are: to perform Anaerobic Digestion batch tests at difference ratios of POME and EFB; to characterize important parameters for the mixture of POME and EFB at different ratios with comparison of the effluent discharge standards; and to evaluate the parameter of removal efficiency of different ratios of POME and EFB.

Based on a thorough review, there are many methods to generate biogas from palm oil biomass. These may be economical or expensive, depending on the capability of the palm oil mill operators involved in the process to optimize their production of by-products. The scope of this analysis of biogas from the biomass residuals of palm oil mill includes the process of treating palm oil mill residue using an anaerobic digestion batch test. The treatment includes the biogas production at different ratios of POME and EFB. As the control temperature and $\mathrm{pH}$, this test was conducted at a laboratory scale and then will be recorded up to 30 days. Characteristic analyses for the initial, operational and effluent phases had to be conducted for comparisons of different ratios of POME and EFB.

This study is meant to fill the gap from previous studies in terms of biogas productions from the POME or the combination of POME and EFB which normally been conducted under the thermophilic conditions. 
A combination between POME and EFB in anaerobic digestion will reduce time of treatment and space. The current study is significant as the effectiveness of POME and EFB mixture were tested using the batch design which consist of the low temperature (mesophilic, 20$40{ }^{\circ} \mathrm{C}$ ) conditions. The mesophilic condition process required energy saving and low-cost process compared to the previous studies which used the high temperature (thermophilic, $41-122{ }^{\circ} \mathrm{C}$ ) that definitely was costly and needed more energy consumption. Biogas production with the proper temperature control will ensure that methanogenic bacteria work.

The combination of EFB and POME in anaerobic digestion treatment may give some ideas for industry to expand and manage their by-product capability. In addition, academia and government agencies must be convinced to conduct research on new fuel resources and to invest more into the sustainable energy resources due to fossil fuel depletion and environmental issues.

\section{EXPERIMENTAL SETUP}

Figure 1 shows the schematic diagram of the experimental setup of an anaerobic digester for conducting the batch test analysis.

\section{SAMPLE PREPARATION}

The substrate composition consists of POME, EFB and seed sludge for performing the biogas production. The mixings are different for each glass vessel for analysing the efficiency of biogas production. The first composition was $160 \mathrm{~mL}$ of fresh POME mixed with $40 \mathrm{~g}$ of EFB, shredded and blended with $1800 \mathrm{~mL}$ seed sludge. This was labelled Biogas 1. In another glass vessel, the composition $120 \mathrm{~mL}$ of fresh POME mixed with $80 \mathrm{~g}$ of EFB was shredded and blended with $1800 \mathrm{~mL}$ seed sludge. This was labelled Biogas 2.

The samples of raw POME and EFB used as a substrate for the cultivation of mixed culture were collected from Kluang, Johor and preserved at $4{ }^{\circ} \mathrm{C}$ to minimize the contamination that could physicochemically affect the sample. The characteristics of raw POME were analysed based on effluent standards (Kheang et al. 2009).

\section{BATCH DIGESTER}

The laboratory scale anaerobic batch digesters used were made from glass, with a total volume of $3 \mathrm{~L}$ and working volume of $2 \mathrm{~L}$. The digesters were operated at ambient (room) temperature. The digester temperature was controlled in the mesophilic range using a digital precise circulation water bath with a hydraulic retention time of 30 days.

Biogas production from the digesters was measured daily via the water displacement method. The volume of water displaced from the flask was equivalent to the volume of gas generated. The reactor was stirred using magnetic continually stirrer. A pH meter was attached to the glass vessel in order to obtain the data daily. A dosing of buffer was required in the initial stage, as the methanogens were not quick enough to convert acetic acid to methane (Poh \& Chong 2010).

\section{ANALYTICAL METHOD}

Characterization of feedstock is one of the most significant steps in the biogas production process. Determining the general composition of the substrate is essential for calculating the quantity and composition of the biogas generated. The efficiency of the removal after treatment was determined using the analytical method for the initial and the effluent characterization. Characteristic parameters of the Biogas 1 and Biogas 2, such as total solids (TS), volatile solids (VS), biochemical oxygen demand (BOD), chemical oxygen demand (COD), total nitrogen (TN), and ammonia nitrate $\left(\mathrm{NH}_{3}\right)$, were determined using standard methods via a Spectrophotometer DR 2000.

A dilution process was conducted due to the high impurity levels and turbidity of the sample. $1 \mathrm{~mL}$ samples were diluted with $500 \mathrm{~mL}$ of deionized water. This dilution process was required to ensure that the spectrophotometer was able to be read, despite equipment limitations.

\section{RESULTS \& DISCUSSION}

\section{ANALYSIS OF THE BIOGAS PRODUCTION}

The compositions ratio of POME and EFB that were considered in this study are based on the reference ratios from Nurliyana et al. (2015) and Octiva et al. (2018). Nurliyana et al. (2015) conducted on methane productivity and biodegradability for few ratios of POME and EFB under the facultative conditions, while Octiva et al. (2018) conducted the biogas production by varying the mixing ratio of POME and EFB in volume/mass under thermophilic condition $\left(55^{\circ} \mathrm{C}\right)$.

The total volume of biogas collected from anaerobic batch test digester at control temperature (mesophilic) as described by Bala et al. (2014) offered good process stability and optimum $\mathrm{pH}$ for most microbial growth. Figure 2 shows the biogas productions within 30 days which illustrated that the Biogas 1 produced 1.02-fold higher accumulations of biogas than Biogas 2. This 


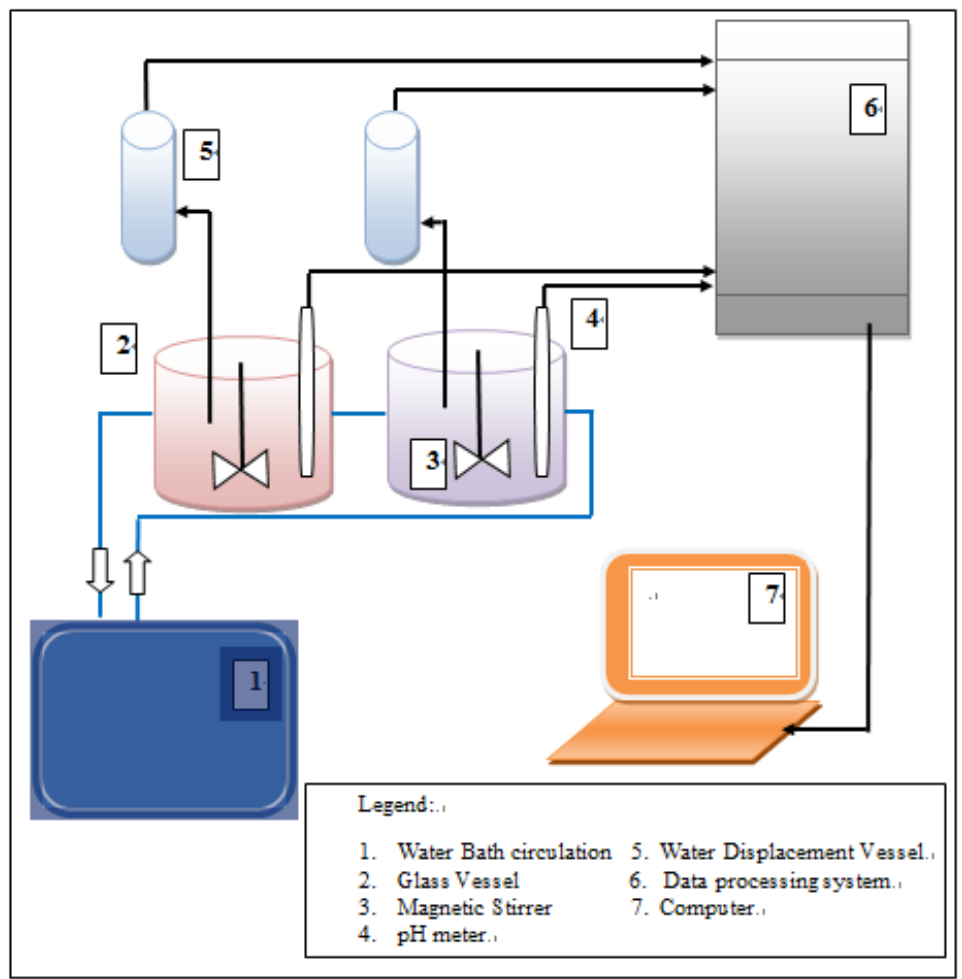

FIGURE 1. Experimental setup of anaerobic digester

may suggest that the additional lignocellulosic biomass degradations present in Biogas 2 was not effective due to the potential cellulolytic microbial activity on the bacterial degradation were more restricted to the biomass which contain low amount of lignin (de Souza 2013). At the initial conditions in day-1, the accumulation of Biogas 1 found to be slightly more than Biogas 2; however, the accumulation of Biogas 1 was found to be lower than Biogas 2 from day-16 to day-28. The different trend of accumulation graph for both Biogas 1 and 2 are due to the factors of microbial activity and stability in the system which should be run under optimal conditions during the hydrolysis, acidogenesis, acetogenesis and methanogenesis phases. This is also supported by Enzmann (2018) and Hamzah et al. (2019).

The optimum $\mathrm{pH}$ was between 6.8 - 7.2. Based on the experimental plan, the biogas produced was based on the different ratio of substrate in the digester. Initially, Biogas 1 produced $1600 \mathrm{~mL}$ of gases on the first day of the experiment. Biogas collection increased day by day for 30 days. The accumulation of Biogas 1 was recorded as $40200 \mathrm{~mL}$. Biogas 2 produced $1300 \mathrm{~mL}$ of biogas. The accumulated of Biogas 2 reached $39500 \mathrm{~mL}$, as the gas was also produced continually.

The Volatile Fatty Acids (VFA) concentrations indicates the presence of anaerobic microorganisms which act as the intermediates in the conversion of organic material to methane (Zhao 2011). The ratio of EFB as the co-substrate may affect the production of biogas if it is not in a proper mixture during the operation. Thus, in this study, the ratio of the substrate may have influenced methane gas production. Furthermore, EFB is woody, and substrates such as cellulose, hemicellulose or lignin mean that the EFB is more difficult to degrade (Kavitha et al. 2013).

In terms of the production of biogas in daily operations, more Biogas 1 was produced consistently than Biogas 2. This might be due to the higher EFB percentage in Biogas 2 not mixing well with the substrate in the glass vessel (Chaikitkaew et al. 2015). EFB's protective shield and hydrophobic nature means that lignin retards cellulose accessibility to enzymes and microbial attacks, leading to lower cellulose and hemicellulose degradation.

After 9 days of the experimental run, on $20^{\text {th }}$ October 2019, Biogas 2 gas production reached 2400 $\mathrm{mL}$, as compared to Biogas 1, which reached $2150 \mathrm{~mL}$. After several days of continuous magnetic stirring in a glass vessel, EFB was well degraded. The graph shown in Figure 3 for both Biogas 1 and 2, had moderately the same inconsistent trend of the biogas production. Surprisingly, from $25^{\text {th }}$ October until $30^{\text {th }}$ October 2019, the biogas 
produced was inversely proportional. If the Biogas 1 production increased in production for the day, Biogas
2 decreased on the same day. This situation remained the same for 5 days. The day after on $31^{\text {st }}$ October 2019,

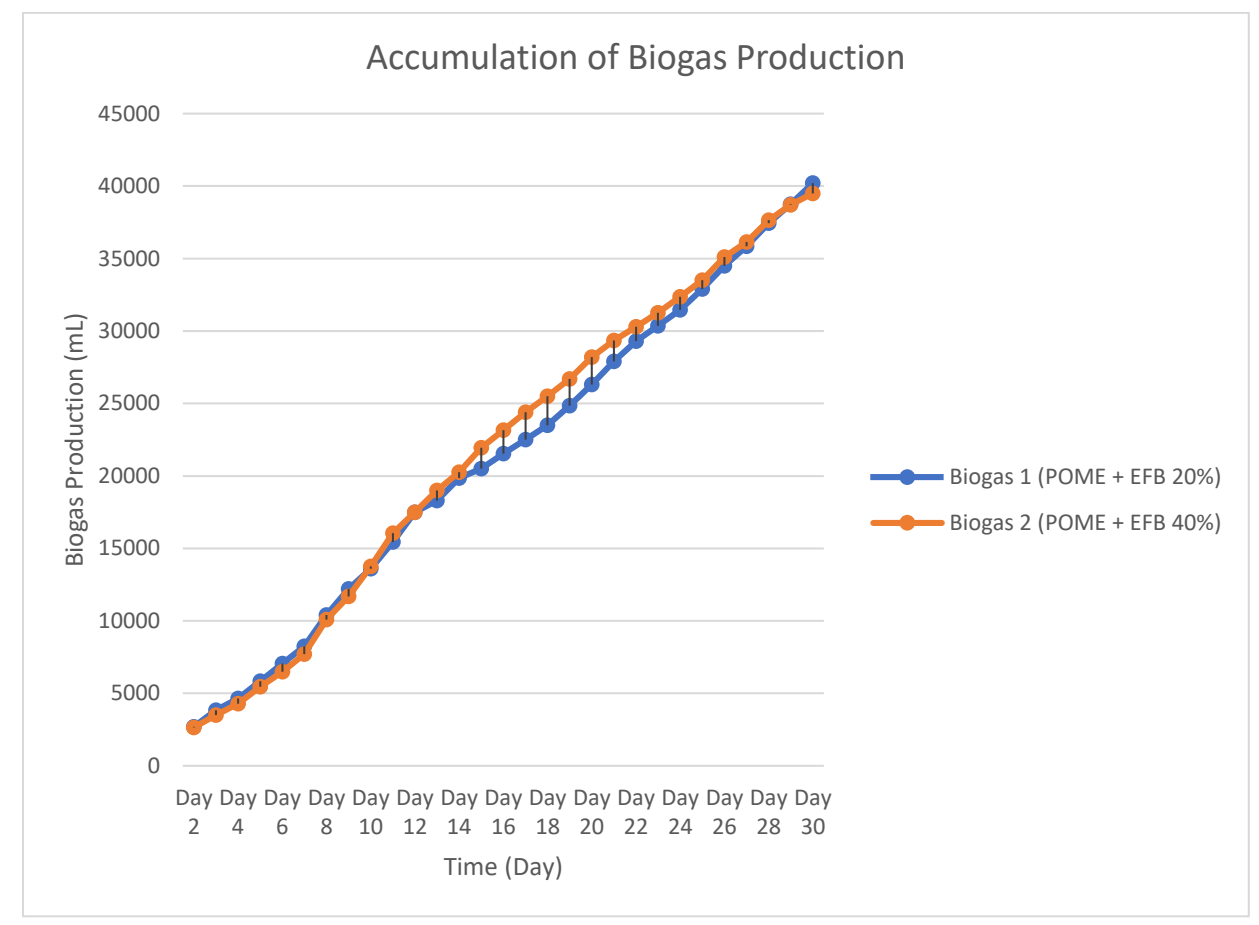

FIGURE 2. Accumulations of biogas production for POME mixed EFB 20\% and POME mixed EFB $40 \%$ in 30 days

the trend returned until $11^{\text {th }}$ November 2019 , but with different levels of biogas. The production of Biogas 1 was higher than Biogas 2 until it reached 30 days of operation. In total, Biogas 1 produced more biogas than Biogas 2.

Table 1 shows a comparison of biogas productivity from the previous research. Compared with the current study, the production of biogas using EFB and mushrooms was lower than using POME and EFB by 0.9 -fold. A later study by Mamimin et al. (2021) showed significant findings for straw mushroom cultivation as an improvement over empty fruit bunches in terms of biodegradability and biogas production.

TABLE 1. Biogas productivity based on previous research

\begin{tabular}{lcc}
\hline \multicolumn{1}{c}{ Materials \& ratio } & Total biogas productivity & Reference (s) \\
\hline Raw EFB : POME 20:5 & $50.4 \mathrm{~m}^{3} /$ tonne & \\
S-mEFB : POME 20:5 & $73.3 \mathrm{~m}^{3} /$ tonne & \\
S-mEFB : POME 20:10 & $72 \mathrm{~m}^{3} /$ tonne & Mamimin et al. (2021) \\
S-mEFB : POME 20:15 & $65.3 \mathrm{~m}^{3} /$ tonne & \\
S-mEFB : POME 20:20 & $55.3 \mathrm{~m}^{3} /$ tonne & \\
*S-Mefb :- spent mushroom-empty fruit bunch & & \\
POME:EFB 35:1 & $80.30 \mathrm{~L} / \mathrm{mg}$ & Octiva et al. (2018) \\
POME:EFB 4.5-7.5:3-36 & $320 \mathrm{~mL} / \mathrm{mg}$ & Saelor et al. (2017) \\
EFB:Mushroom media 1:4 & $37.462 \mathrm{~L}$ & Purnoma et al. (2017) \\
Oil palm biomass :Inoculum 2:1 & $2180-130 \mathrm{~mL} / \mathrm{g}$ & Srisuda et al. (2015) \\
POME:EFB:press water seed 0.9:0.1:1 & $218 \mathrm{~mL} \mathrm{CH4/g}$ & Kanokwan et al. (2014) \\
\hline
\end{tabular}


In summary, EFB shows potential in biogas production when mixed with POME. The EFB ratio was higher than POME for Biogas 2 on the $20^{\text {th }}$ October 2019, leading biogas production for several days. This may serve as a valuable indicator for the use of EFB in the production of biogas.

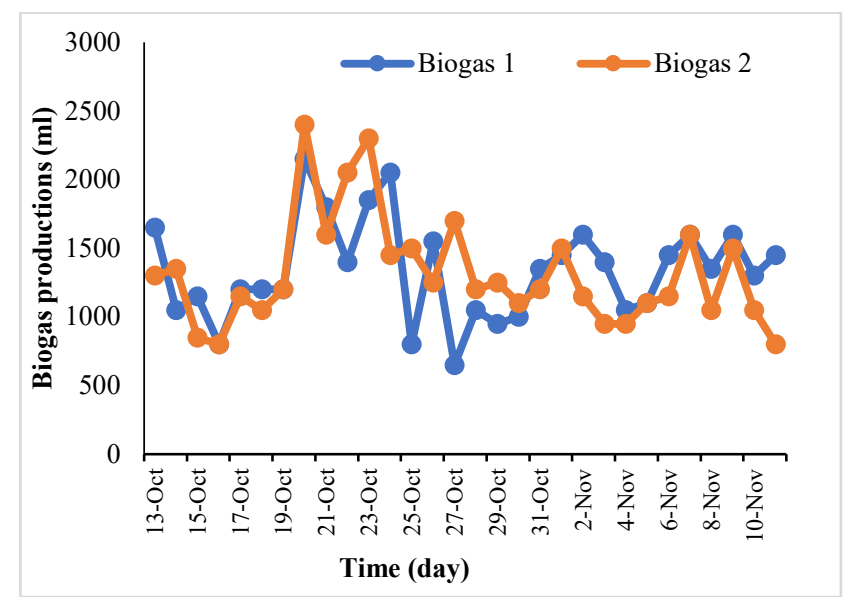

FIGURE 3. Daily trend of biogas production for POME mixed with EFB $20 \%$ and POME mixed with EFB 40\%

\section{PARAMETER REMOVAL ANALYSIS}

In this study, the characteristics of raw mixtures of POME and EFB at different ratios have been determined. The significance of parameter analysis is to evaluate the effects of each condition on the performance reaction for varying ratios of POME and EFB mixtures. The initial values of parameters listed in Table 2 for the POME and EFB mixtures of Biogas 1 are higher than the values of mixture for Biogas 2, as represented in Figure 5.

TABLE 2. Comparisons of effluent from Biogas 1 and Biogas 2 with parameters limits in respective standard discharge levels set by the Malaysian Department of the Environment

\begin{tabular}{|c|c|c|c|c|c|c|c|c|}
\hline \multirow[t]{2}{*}{ Parameter } & \multirow[t]{2}{*}{ Units } & \multirow[t]{2}{*}{$\begin{array}{c}\text { Standard } \\
\text { limit }\end{array}$} & \multicolumn{2}{|c|}{ Initial concentrations } & \multicolumn{2}{|c|}{ Effluent } & \multicolumn{2}{|c|}{$\begin{array}{l}\text { Percentage of } \\
\text { removal }(\%)\end{array}$} \\
\hline & & & Biogas 1 & Biogas 2 & Biogas 1 & Biogas 2 & Biogas 1 & Biogas 2 \\
\hline $\begin{array}{l}\text { Biochemical Oxygen } \\
\text { Demand (BOD) }\end{array}$ & $\mathrm{mg} / \mathrm{L}$ & 100 & 4480 & 399.4 & 840 & 1010 & 81.3 & 74.7 \\
\hline Chemical Oxygen & & & & & & & & \\
\hline Demand (COD) & $\mathrm{mg} / \mathrm{L}$ & $50-100$ & 20300 & 18600 & 2450 & 5044 & 87.9 & 72.9 \\
\hline Total solid & $\mathrm{mg} / \mathrm{L}$ & - & 18981 & 17455 & 9103 & 10320 & 52.0 & 40.9 \\
\hline Volatile solids & $\mathrm{mg} / \mathrm{L}$ & - & 8905 & 9145 & 4791 & 4020 & 46.2 & 56.0 \\
\hline Ammonia nitrogen & $\mathrm{mg} / \mathrm{L}$ & 150 & 1240 & 1500 & 750 & 1100 & 39.5 & 26.7 \\
\hline Total nitrogen & $\mathrm{mg} / \mathrm{L}$ & 200 & 1300 & 800 & 405 & 125 & 68.8 & 84.4 \\
\hline $\mathrm{pH}$ & - & $5-9$ & - & - & 7.3 & 7.2 & - & - \\
\hline Temperature & ${ }^{0} \mathrm{C}$ & 45 & - & - & 39 & 39 & - & - \\
\hline
\end{tabular}


After two weeks of operation for the anaerobic batch test, sample from Biogas 1 and Biogas 2 underwent further characteristic analysis. Table 2 presented the percentage of removal in Biogas 1 were higher than Biogas 2 for BOD, COD, TS and Ammoniacal Nitrogen. These findings were also supported by Octiva et al. (2018) for the COD removal. The biogas production from Biogas 1 also found to be higher than Biogas 2 which these conditions indicated that methanogenic bacteria were actively working on the impurities inside the sample. In order to determine the effectiveness of the batch design under the mesophilic conditions at the end of the process, parameters' effluent levels for Biogas 1 and Biogas 2 had been compared with the allowable discharge standards specified by the Department of Environment (DOE), Malaysia. The final effluent samples from Biogas 1 and Biogas 2 were still not comply with effluent discharge standards for related parameters as tabulated in Table 2. Thus, additional simple treatment is needed before discharging such effluent to the stream.

Although characterizing important parameters for the mixture of POME and EFB at different ratio with comparison of the effluent discharge standard has not been completed, it is indicated that anaerobic digestion is a valuable holistic approach of treating such waste (mixed of biomass residue of palm oil mills). In this way, the production of biogas would be more sustainable economically. With further treatment, all impurities will be flushed and meet standard requirements. This will mean a more economically and environmentally friendly process for treating the biomass residue of palm oil mills.

The $\mathrm{BOD}_{5} / \mathrm{COD}$ of the mixture POME and EFB with varying ratio of $0.22: 0.21$ according to Biogas 1 and Biogas 2, respectively. This indicates that these two wastewater sample have the ability to be biodegraded by microorganisms because of their $\mathrm{BOD}_{5} / \mathrm{COD}$ ratio was more than 0.1 (Kanokwan et al. 2014). Based on Figures 4 and 5, there were three conditions under which parameter analysis was conducted. The conditions represent the initial, operational, and final effluent phases for both Biogas 1 and Biogas 2, respectively. The trend in reduction of contaminant in Biogas 1 is the same as Biogas 2. All experiments found that the TS effluent, VS effluent, BOD effluent, and COD effluent decreased, indicating that the decomposition of organic matter in the system converted into biogas production. When biodegradation by microorganisms occurred in the system, many factors changed, including the parameters of $\mathrm{NH}_{3}-\mathrm{N}$ and TN. Analysis of TS clearly has the lowest percentage removal of TS for Biogas 2 during the operation and final conditions. This is due to Biogas 2 consists of a higher ratio of EFB ( $40 \% \mathrm{EFB})$ compared to the Biogas 1 (20\% EFB).

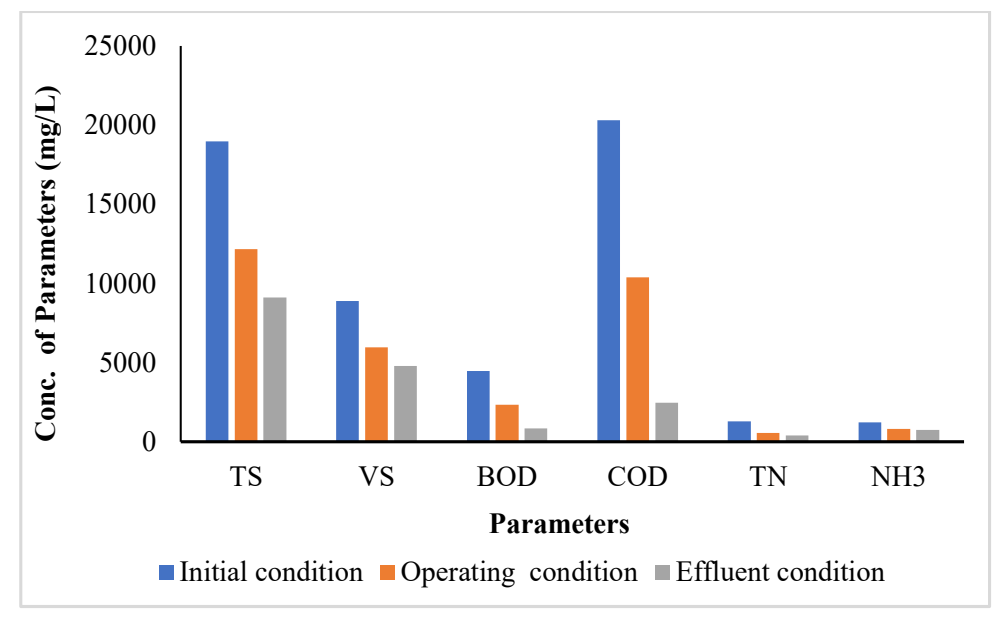

FIGURE 4. Parameter analysis for initial, operational, and effluent conditions for Biogas 1 


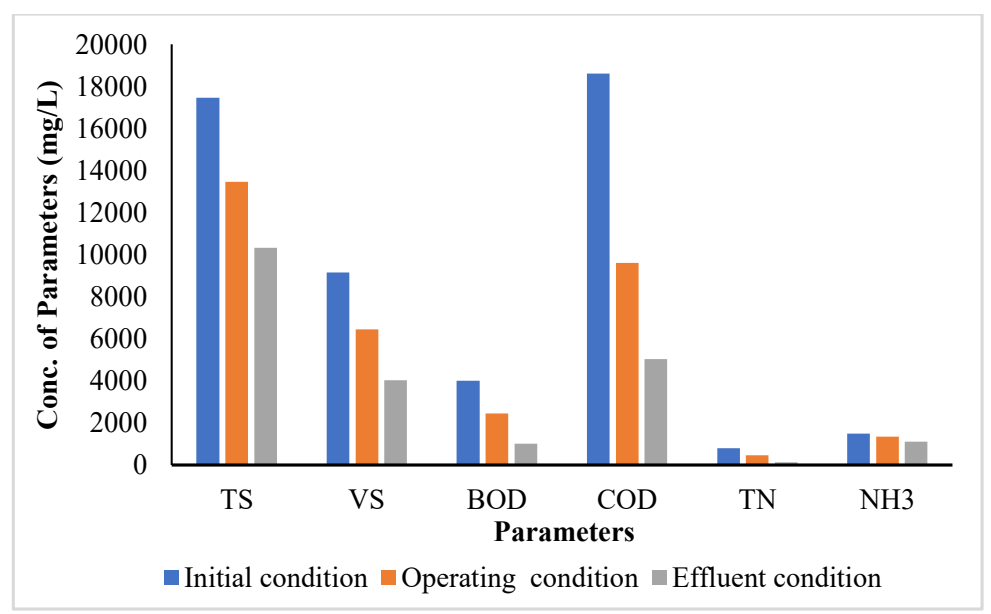

FIGURE 5. Parameter analysis for initial, operating, and effluent conditions for Biogas 2

This is also supported by results from Kavitha et al. (2013) as lower removal may be due to the high organic carbon content allied with humid substances present in mixture of POME and EFB. The woody characteristics of EFB mentioned by Kavitha et al. (2013) that might slow the degradation process and reduce ability in TS reduction. Values of percentage removal for VS was not varying much, showing that that different organic compounds have varying degradability speeds. The ratio of TS/VS for Biogas 1 is higher than that of Biogas 2 , indicating higher levels of methane production for Biogas 1.

For the operational condition, BOD for Biogas 1 is $2340.8 \mathrm{mg} / \mathrm{L}$ with $47.7 \%$ removal and Biogas 2 is $2449.4 \mathrm{mg} / \mathrm{L}$ with $38.7 \%$ removal. For BOD, total removal efficiency for Biogas 1 is $81 \%$ and that of Biogas 2 is $74.7 \%$. Hence, Biogas 1 has higher BOD removal ability than Biogas 2, meaning that the resulting effluent has less organic matter. This mean that the microorganisms will consume less oxygen to decompose organic matter in the effluent (Ibrahim et al. 2012).

To measure the oxygen equivalent of the organic material in wastewater by COD analysis (Ibrahim et al. 2012). The COD value under initial conditions for Biogas 1 was $20300 \mathrm{mg} / \mathrm{L}$ and that of effluent condition was 2450 $\mathrm{mg} / \mathrm{L}$. COD present in Biogas 2 under initial conditions was $18600 \mathrm{mg} / \mathrm{L}$ and that under effluent conditions was $5044 \mathrm{mg} / \mathrm{L}$. COD removal for Biogas 1 reached $87.9 \%$, while that of Biogas 2 was $72.8 \%$. Both samples had good COD removal because process performance in the reactors was stable, with COD removal efficiencies of $73.0-85.9 \%$, This is similar to findings by Bala et al.
(2014). Stability was measured using influent and effluent COD concentrations. According to Poh and Chong (2010), the COD removal efficiency of a system is highly reliant on the $\mathrm{pH}$ of the system during start-up. In this study, the $\mathrm{pH}$ is a control variable $(\mathrm{pH} 7)$. This results in high efficiency of COD removal for both samples. The COD removal efficiency of Biogas 1 was higher than Biogas 2 because of the use of the organic compounds to produce biogas.

\section{CONCLUSION \& FUTURE WORKS}

According to the results of analysis from the batch test, it can be concluded that the mixed combination of POME and EFB may allow for biogas production. EFB could serve as an additional substrate for the POME to optimize the biogas production during the mesophilic conditions. The findings also show that the ratio of POME and $20 \%$ EFB (Biogas 1) was more efficient in biogas production compared to POME and $40 \%$ EFB (Biogas 2). The percentage removal of related parameters had been found to be higher in Biogas 1 compared to Biogas 2 for BOD, COD, TS, and Ammoniacal Nitrogen. Findings from this study will serve as preliminary results for enhancing the treatment methods use in Malaysia. Most industries have realized the potential of POME as the resource for biogas production and pollutant removal. However, there is a lack of awareness on EFB as a co-substrate for the biogas production. Therefore, this study can help related stakeholders increase value and generate higher profits by multiplying production of by-products. As for future recommendations, this study will be continued using other 
ratios of POME and EFB to increase biogas productivity and the effectiveness of pollutant removal.

\section{REFERENCES}

Ahmad, A., Ismail, S. \& Bhatia, S. 2003. Water recycling from palm oil mill effluent (POME) using membrane technology. Desalination 157(1-3): 87-95.

Baharuddin, A.S., Hock, L.S., Yusof, M.Z., Abdul, N.A., Shah, U., Hassan, M.A., Sakai, K. \& Shirai, Y. 2010. The effect of palm oil mill effluent (POME) anaerobic sludge from $500 \mathrm{~m}^{3}$ of closed anaerobic methane digested tank on pressed-shredded empty fruit bunch (EFB) composting process. African Journal of Biotechnology 9(16): 2427-2436.

Bala, J.D., Lalung, J. \& Ismail, N. 2014. Palm oil mill effluent (POME) treatment "microbial communities in an anaerobic digester": A review. International Journal of Scientific and Research Publications 4(6): 1-24.

Chaikitkaew, S., Kongjan, P. \& O-Thong, S. 2015. Biogas production from biomass residues of palm oil mill by solid state anaerobic digestion. Energy Procedia 79: 838-844.

Choong, C.G. \& McKay, A. 2014. Sustainability in the Malaysian palm oil industry. Journal of Cleaner Production 85: 258264.

de Souza, W.R. 2013. Microbial degradation of lignocellulosic biomass. In Sustainable Degradation of Lignocellulosic Biomass-Techniques, Applications and Commercialization, edited by Chandel, A.K. \& da Silva, S.S. United Kingdom: IntechOpen. pp. 207-247.

Enzmann, F., Mayer, F., Rother, M. \& Holtmann, D. 2018. Methanogens: Biochemical background and biotechnological applications. $A M B$ Express 8(1): 1-22.

Hamzah, M.A.F., Jahim, M.J., Abdul, P.M. \& Asis, A.J. 2019. Investigation of temperature effect on start-up operation from anaerobic digestion of acidified palm oil mill effluent. Energies 12(13): 2473.

Hasanudin, U., Sugiharto, R., Haryanto, A., Setiadi, T. \& Fujie, K. 2015. Palm oil mill effluent treatment and utilization to ensure the sustainability of palm oil industries. Water Science and Technology 72(7): 1089-1095.

Ibrahim, A.H., Dahlan, I., Adlan, M.N. \& Dasti, A.F. 2012. Comparative study on characterization of Malaysian palm oil mill effluent. Research Journal of Chemical Sciences 2(12): $1-5$.

Kanokwan, J., Nutthatus, C.A. \& Thunwadee, T.S. 2014. Enhancing of methane production from palm oil mill effluent by co-digestion with empty fruit bunch pressed wastewater at mesophilic condition using an Anaerobic batch reactor. SCIENCE PLUS International Conference. pp. 28-30.

Kavitha, B., Jothimani, P. \& Rajannan, G. 2013. Empty fruit bunch-a potential organic manure for agriculture. International Journal of Science Environment 2(5): 930-937.

Kheang, L.S., Mohammad, N.F. \& Ngan, M.A. 2009. Characterization of palm oil mill effluent (POME) for process control baseline establishment. MPOB Information Series, ISSN.
Mamimin, C., Chanthong, S., Leamdum, C., Sompong, O. \& Prasertsan, P. 2021. Improvement of empty palm fruit bunches biodegradability and biogas production by integrating the straw mushroom cultivation as a pretreatment in the solid-state anaerobic digestion. Bioresource Technology 319: 124227.

Nurliyanaa, M.Y., H’nga, P.S., Rasminaa, H., Umi Kalsomb, M.S., Chinc, K.L., Leea, S.H., Luma, W.C. \& Khooa, G.D. 2015. Effect of $\mathrm{C} / \mathrm{N}$ ratio in methane productivity and biodegradability during facultative co-digestion of palm oil mill effluent and empty fruit bunch. Industrial Crops and Products 76: 409-415.

Octiva, C.S., Irvan, M., Sarah, B., Trisakti. \& Daimon, H. 2018. Production of biogas from co-digestion of empty fruit bunches (EFB) with palm oil mill effluent (POME): Effect of mixing ratio. Journal of Chemistry 11(2): 791-797.

Pleanjai Somporn, H., Gheewala, S. \& Garivait, S. 2004. Environmental evaluation of biodiesel production from palm oil in a life cycle perspective. Asian Journal on Energy and Environment 8(1): 15-32.

Poh, P.E. \& Chong, M.F. 2010. Thermophilic palm oil mill effluent (POME) treatment using a mixed culture cultivated from POME. Chemical Engineering Transactions 21: 811816.

Prasertsan, S. \& Prasertsan, P. 1996. Biomass residues from palm oil mills in Thailand: An overview on quantity and potential usage. Biomass and Bioenergy 11(5): 387-395.

Purnomo, A., Suprihatin, Romli, M. \& Hasanudin, U. 2018. Biogas production from oil palm empty fruit bunches of post mushroom cultivation media. Earth and Environmental Science 141(1): 012024.

Saelor, S., Kongjan, P. \& Sompong, O. 2017. Biogas productions from anaerobic co-digestion of palm oil mill effluent and empty fruit bunches. Energy Procedia 138: 717-722.

Schuchardt, F., Wulfert, K., Darnoko. \& Herawan, T. 2008. Effect of new palm oil mill processes on the EFB and pome utilization. Journal of Oil Palm Research 20: 115-126.

Srisuda, C., Prawit, K. \& Sompong, O.T. 2015. Biogas production from biomass residues of palm oil mill by solid state anaerobic digestion. Energy Procedia 79: 838-844.

Sulaiman, F., Abdullah, N., Gerhauser, H. \& Shariff, A. 2011. An outlook of Malaysian energy, oil palm industry and its utilization of wastes as useful resources. Biomass and Bioenergy 35(9): 3775-3786.

Wu, T.Y., Mohammad, A.W., Jahim, J.M. \& Anuar, N. 2010. Pollution control technologies for the treatment of palm oil ill effluent (POME) through end-of-pipe processes. Journal of Environmental Management 91(7): 1467-1490.

Yacob, S.Y., Shirai, M.A., Hassan, M., Wakisaka. \& Subash, S. 2006. Start-up operation of semi-commercial closed anaerobic digester for palm oil mill effluent treatment. Process Biochemistry 41: 962-964.

Zhao, C. 2011. Effect of temperature on biogas production in anaerobic treatment of domestic wastewater UASB system in Hammarby Sjöstadsverk Chengyuan Zhao. Royal Institute of Technology (KTH). MSc Thesis (Unpublished). 
Norashikin Ahmad Kamal*, Siti Nooraihanah Osman \& Marfiah Ab Wahid

Faculty of Civil Engineering

Universiti Teknologi MARA

40450 Shah Alam, Selangor Darul Ehsan

Malaysia
Lee Dong Yeol

GS E\&C

Seoul

South Korea

*Corresponding author; email: norashikin7349@uitm.edu.my

Received: 5 July 2020

Accepted: 4 April 2021 